\title{
Catastrophic cerebral sinovenous thrombosis with haemorrhagic conversion in a new diagnosis of paediatric acute myelogenous leukaemia
}

\author{
C Nathan Nessle 자, ${ }^{1}$ Francisco Rivas-Rodriguez, ${ }^{2}$ Angela C. Weyand ${ }^{3}$
}

${ }^{1}$ Pediatric Hematology Oncology, University of Michigan Medical School, Ann Arbor, Michigan, USA

${ }^{2}$ Radiology, Division of Neuroradiology, Michigan Medicine, University of Michigan, Ann Arbor, Michigan, USA

${ }^{3}$ Pediatric Hematology Oncology, University of Michigan Hospital, Ann Arbor, Michigan, USA

Correspondence to Dr C Nathan Nessle; cnessle@med.umich.edu

Accepted 25 May 2021

\section{DESCRIPTION}

A previously healthy 14-month-old boy with 5 days of cough, rhinorrhea, diarrhoea and fever to $38.9^{\circ} \mathrm{C}$ was admitted to an outside hospital with altered mental status, intermittent bradycardia and hypertension, but otherwise a normal physical examination. A complete blood count $(\mathrm{CBC})$ revealed leucocytosis $(33 \mathrm{k} / \mu \mathrm{L})$, anaemia $(10.4 \mathrm{~g} / \mathrm{dL})$, thrombocytopaenia $(48 \mathrm{k} / \mu \mathrm{L})$ and peripheral blasts; flow cytometry showed an aberrant blast population positive for CD4, CD11b, CD11c, CD15, CD33, CD38, CD45, CD56, CD123, negative for TdT and cMPO, and cancer cytogenetics revealed KMT2A (MLL)-MLLT3 $\mathrm{t}(9 ; 11)(\mathrm{p} 22 ; \mathrm{q} 23)$, consistent with acute myelogenous leukaemia (AML) with monocytic features (FAB M5). Coagulation studies revealed disseminated intravascular coagulopathy (DIC) with elevated international normalized ratio (INR) (1.6), decreased fibrinogen $(107 \mathrm{mg} / \mathrm{dL})$ and elevated D-dimer $(7286 \mathrm{ng} / \mathrm{mL}$ (normal $<255 \mathrm{ng} /$ $\mathrm{mL}$ ); International Society of Thrombosis and Hemostasis DIC Score was 5. MRI of the brain demonstrated a bilateral thalamic mass lesion, with blood degradation products and restricted diffusion, extending to the left midbrain measuring $6 \mathrm{~cm}$ $\times 4 \mathrm{~cm} \times 4 \mathrm{~cm}$ (figure 1 ).

Eighteen hours into his admission, he was transferred to our institution intubated, sedated and critically ill. On physical examination, there was no evidence of petechiae or bruising. However, he did have new anisocoria and sluggish pupillary reactivity with decorticate posturing, thus medical interventions for elevated intracranial pressure were initiated. Repeat CBC demonstrated leucocytosis $(56 \mathrm{k} / \mu \mathrm{L})$ and absolute blast count of $15.7 \mathrm{k} /$

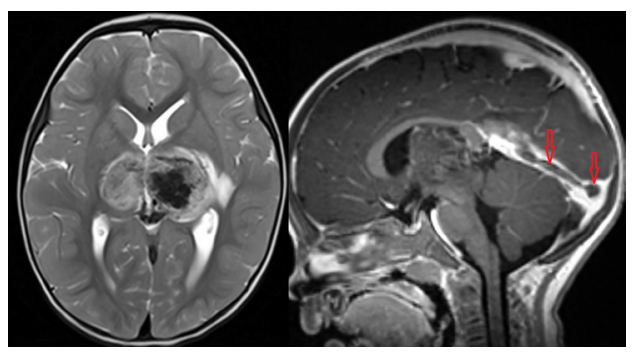

(c) BMJ Publishing Group Limited 2021. No commercial re-use. See rights and permissions. Published by BMJ.

\begin{tabular}{|l|}
\hline To cite: Nessle CN, \\
Rivas-Rodriguez F, \\
Weyand AC. BMJ Case \\
Rep 2021:14:e242873. \\
doi:10.1136/bcr-2021- \\
242873 \\
\hline
\end{tabular}

Figure $1 \mathrm{MRI}$, brain. Axial T2-weighted image demonstrates a bilateral thalamic heterogeneous lesion, with abnormal increased T2 signal representing oedema. Sagittal T1-weighted postgadolinium image demonstrates a filling defect, representing thrombosis, along the straight sinus and confluence of sinuses. $\mu \mathrm{L}$. Interpretation of the outside MRI of the brain favoured bilateral thalamic haemorrhagic venous infarcts; follow-up CT of the head demonstrated extensive haemorrhagic infarcts in bilateral thalami and basal ganglia, growth of acute intraparenchymal haematoma with intraventricular extension and severe ventriculomegaly. CT venography confirmed extensive deep venous sinus thrombosis. The patient was taken emergently to the operating room by neurosurgery for bilateral frontal ventriculostomies. Despite surgical decompression, vasopressor support, rapid anticoagulation and chemotherapy administration, he succumbed to refractory intracranial hypertension several hours after the procedure. The family compassionately withdrew care the following day.

In patients with acute leukaemia and altered mental status, thrombotic or coagulopathic complications are associated with high mortality and require high suspicion in diagnosis to ensure timely management. The hypercoagulable state in acute leukaemia is attributed to a complex interaction of prothrombotic factors and cancer procoagulant produced by leukaemic cells, inflammatory cytokines, central venous catheter placement, chemotherapy and comorbid thrombophilia. ${ }^{1}$ While haemorrhage is the most common manifestation of DIC in patients with paediatric cancer, thrombotic events (TEs) occur less frequently with varied incidence of $1.2 \%-16 \%$ and over half manifesting as central nervous system thrombosis. ${ }^{2-4}$ Patients with AML are three times more likely to have TE at the time of diagnosis compared with patients with acute lymphoblastic leukaemia, who are more likely to develop thrombosis during treatment. ${ }^{3}$ Although coagulopathy is classically associated with acute promyelocytic leukaemia (APML) (FAB M3), DIC is seen in one-third of non-APML subtypes such as M5 AML in our patient. ${ }^{5}$ Transfusion of platelets and fresh frozen plasma are the most frequently reported supportive measures, as well as anticoagulation when thrombosis is present. ${ }^{4}$

Cerebral sinovenous thrombosis (CSVT) is the most common type of central nervous system TE and most frequently diagnosed at presentation or early in therapy. ${ }^{26}$ Therapeutic anticoagulation is recommended by international guidelines in adults with CSVT with haemorrhagic transformation.? Anticoagulation in paediatric CSVT with haemorrhagic conversion has shown reduction in mortality and improvement in long-term morbidity, although institutional practices may vary. ${ }^{8}$ 


\section{Learning points}

Diagnosis of thrombotic events (TEs) require a high degree of suspicion.

- Cerebral sinovenous thrombosis (CSVT) is the most common central nervous system TE in acute myelogenous leukaemia (AML).

- TEs occur more frequently at time of diagnosis in AML compared with ALL.

Contributors CNN and ACW conceptualised the report, and planned the data and information needed to emphasise the learning points. CNN performed data collection, performed literature and chart review, wrote the initial draft, assisted in interpretation of data, and assisted in editing. FR-R assisted in report conceptualisation, interpreted the diagnostic imaging, determined and selected the most impactful MR images, edited and formatted the images, provided interpretation of imaging in the report, and assisted in editing. ACW assisted in literature and chart review, assisted in interpretation of data, edited the manuscript, and oversaw conduct of the report.

Funding This study was funded by National Cancer Institute (T32-CA236621: Interdisciplinary Research Training).

Competing interests None declared.
Patient consent for publication Obtained.

Provenance and peer review Not commissioned; externally peer reviewed.

\section{ORCID iD}

C Nathan Nessle http://orcid.org/0000-0001-7119-1658

\section{REFERENCES}

1 Colombo R, Gallipoli P, Castelli R. Thrombosis and hemostatic abnormalities in hematological malignancies. Clin Lymphoma Myeloma Leuk 2014;14:441-50.

2 Caruso V, lacoviello L, Di Castelnuovo A, et al. Thrombotic complications in childhood acute lymphoblastic leukemia: a meta-analysis of 17 prospective studies comprising 1752 pediatric patients. Blood 2006;108:2216-22.

3 De Stefano V, Sorà F, Rossi E, et al. The risk of thrombosis in patients with acute leukemia: occurrence of thrombosis at diagnosis and during treatment. J Thromb Haemost 2005;3:1985-92

4 Kongstad C, Mikkelsen TS, Hvas A-M. Disseminated intravascular coagulation in children with cancer: a systematic review. Pediatr Hematol Oncol 2020;37:390-411.

5 Uchiumi H, Matsushima T, Yamane A, et al. Prevalence and clinical characteristics of acute myeloid leukemia associated with disseminated intravascular coagulation. Int J Hematol 2007;86:137-42.

6 Noje C, Cohen K, Jordan LC. Hemorrhagic and ischemic stroke in children with cancer Pediatr Neurol 2013;49:237-42.

7 Coutinho J, de Bruijn SF, Deveber G. Anticoagulation for cerebral venous sinus thrombosis. Cochrane Database Syst Rev 2011;8:CD002005.

8 Hutchinson ML, Beslow LA. Hemorrhagic transformation of arterial ischemic and venous stroke in children. Pediatr Neurol 2019;95:26-33.

Copyright 2021 BMJ Publishing Group. All rights reserved. For permission to reuse any of this content visit

https://www.bmj.com/company/products-services/rights-and-licensing/permissions/

BMJ Case Report Fellows may re-use this article for personal use and teaching without any further permission.

Become a Fellow of BMJ Case Reports today and you can:

- Submit as many cases as you like

- Enjoy fast sympathetic peer review and rapid publication of accepted articles

- Access all the published articles

Re-use any of the published material for personal use and teaching without further permission

\section{Customer Service}

If you have any further queries about your subscription, please contact our customer services team on +44 (0) 2071111105 or via email at support@bmj.com.

Visit casereports.bmj.com for more articles like this and to become a Fellow 